\title{
A Framework for Potable Water in the Face of Plenty for Sustainability on Lekki Peninsula of Lagos State, Nigeria
}

\author{
Kofo Aderogba \\ School of Social and Management Sciences, Tai Solarin University of Education, Ijebu-Ode, Nigeria \\ Email: kofoaderogba@yahoo.com
}

Received December 6, 2013; revised January 5, 2014; accepted February 4, 2014

Copyright (C) 2014 Kofo Aderogba. This is an open access article distributed under the Creative Commons Attribution License, which permits unrestricted use, distribution, and reproduction in any medium, provided the original work is properly cited. In accordance of the Creative Commons Attribution License all Copyrights (C) 2014 are reserved for SCIRP and the owner of the intellectual property Kofo Aderogba. All Copyright (C) 2014 are guarded by law and by SCIRP as a guardian.

\begin{abstract}
Peninsulas are exceptional areas loved to be developed uniquely in most part of the globe. Lekki Peninsulas in Lagos, Nigeria is fast growing, benefitting from similar fortunes such as modern residential suburbs, free trade zone, airport; and tourism are springing up but without adequate potable water for sustainable development. Reconnaissance surveys followed by an In-Depth-Interview were carried out. The commonest sources are sachet, bottled and borehole waters. Sachet and bottled waters are readily available but at unaffordable costs. The most frequently available is borehole, but chemical, physical/organoleptic and microbiological analysis show that the compositions are not within WHO permissible standards. Sustainability is in jeopardy. Individuals, organizations and businesses spend average of $15 \%$ of their income on treatments to meet acceptable standards. There are needs to bridge the gap between the residents taking untreated poor water and the few that take WHO standardized waters. A Simple Water Treatment Device is recommended. The device consists of four chambers, two pumping machines, alum and chlorine for treatment. It is equipped with 12 to 13 valves (depending on the position of the chambers); and the entire system is powered by electricity. It will control water borne diseases such as typhoid, schistotomiasis, diarrhea and dysentery, hepatitis, cholera and others; potable water will be available for domestic, recreational and industrial uses; enough for use in the Free Trade Zone and at the forth coming airport; the Eighteen Golf Course will not have challenges of potable water; and forces and military formations within and around the peninsula can rely on the source for every use. It is estimated that the system that can provide average of 100,000 liters of water a day will cost N720,000:00, that is, outside the cost of electricity. The system requires regular maintenance. This device could be applied anywhere.
\end{abstract}

\section{KEYWORDS}

Lekki Peninsula; Lagos New Suburb; Framework; Potable Water; Sustainability

\section{Introduction}

Infrastructural development in Nigeria and in the cities and towns in particular have been abacus and of concern to governments, researches, communities and development; and sustainability had been threatened in all ramifications [1-6]: Power, water, transportation and communication, health care delivery system, education, political systems and others can be censured to be below the United Nations (UN) acceptable standard for sustainable development [7]. Electricity is in shamble: there is nowhere electricity run for 24 hours of any day from national grid; every home in the cities and towns has at least a set of electricity generator and all industrial out puts plough back the cost of self-generated electricity; hospitals are not spatially efficiently located and poorly equipped; education is poorly funded and private sector is taken over at all levels; there is no single city where pipe borne water run in all its nooks and crannies, public taps are things of the past, they are perpetually dry; individuals, groups and organizations dig and maintain their private boreholes and wells; the roads are death traps; and one dear not think of security of lives and properties in any part of the nation. It is all stories of melancholy. Whereas, according to the World Bank [8], the Millennium Development Goal (MDG) target is to reduce by 
half the proportion of people in the urban centers without basic facilities by the year 2015. The year 2015 is around the corner. Water is one of these basic facilities. While the percent of population with access to improved water increased since 1990 in all regions, the number of people living without accessing to potable water has increased due to slow progress and population growth: In 2008, 2.6 billion people still had no access to improved sanitation facilities of which water is 72.50 percent [7].

The UN suggests that each person needs 20 - 50 liters of water a day to ensure their basic needs for drinking, cooking and cleaning [9-11]. Incidentally, in 2010, 89\% of the world's population, or 6.1 billion people, used improved drinking water sources, exceeding the MDG target (88\%); 92\% are expected to have access in 2015. By 2015, 67\% will have access to improved sanitation facilities (the MDG target is 75\%), [12]. This prediction may not be realized because of the ostensible predicament in the access to portable water for drinking, cooking and mere sanitation at Lekki, Lagos in spite of its position-a peninsula in the mist of plenty of water"Water, water, everywhere; but not a drop to drink."

Therefore, the objective of the work is to examine and assess the sources and quality of available water at the Lekki Peninsula of Lagos, Nigeria; and suggest a device that will help to meet the needs of those that cannot afford bottled water in the fast growing Lekki Peninsula and similar locations. The work is limited to potable water. Sea and ocean waters are common on Lekki Peninsula but these are not the concerns of the work. Also, the work is limited to the present built-up areas and the proposed extensions within the Lekki Peninsula.

\section{Lekki Peninsula and Its Uniqueness}

A Peninsula (also called a byland or biland) is simply a piece of land that is bordered by water on three sides but connected to mainland [13]. The surrounding water is usually understood to belong to a single, contiguous body, but not explicitly defined as such. Some cultures call it Baltic or Slavic (Hungarian and Chinese), and half-island (Koreans). It is usually a piece of land that sticks out from a larger area of land into the sea or into a lake, bordered by water on three sides but connected to mainland by an isthmus. Europe is sometimes considered to be a large peninsula because it extends off Eurasia. It is composed of many peninsulas, the four main components being Iberian, Scandinavian, Italian and Balkan peninsulas. Usually, they are considered to be unique and special pieces of land areas designated for special physical development [13,14]. Examples across the globe are Italian, Arabian, Beara, Banks, Antartic, Malay, Aupouri, Bell (formally, Bell Island), Baja, Kaikoura, Au, Iberian, Yacatan, Kurnell, Shimabara andMornington peninsulas; and Lekki and Bakassi peninsulas in Nigeria. Unders- tandably, like most of developed worlds, Lekki Peninsula of Nigeria is unique for its location, relief, drainage, tourism, economic growth pole, real estate capabilities and others.

The Sub-Region comprises a naturally formed peninsula on the Atlantic Ocean East of Lagos City and on Lagos Lagoon. The Peninsula runs parallel to the Atlantic Ocean east of Victoria Island. It is a rapidly growing area on the coast, southwestern Nigeria. It is approximately 70 to $80 \mathrm{~km}$ long, stretching from Victoria Island in the west to Refuge Island in the east with an average width of about $10 \mathrm{~km}$. The Sub-Region includes several Estates, gated residential developments, agricultural farmlands, areas allocated for a Free Trade Zone (FTZ), an airport, and a sea port. There is a project area estimated to be about 60,000 hectares excluding the areas allocated for the Lekki Free Trade Zone, Sea Port and International Airport. There are also vacant lands awaiting other urban and or rural-urban fringe functions. The proposed land use master plan for the Sub-region envisages the Lekki Peninsula as a "Blue-Green" Environment City. The unique characteristics of the Atlantic Coast, Lagos Lagoon and the inland natural areas will be protected and enhanced to give Lekki New City the special natural ambience character. Based on the proposed landuse plan, Lekki new city will be divided into 5 linear development zones (excluding the Lekki Free Trade Zone), namely, [15]:

1) The Atlantic Coastal Zone for tourism and recreations, mainly;

2) The Lagoon Zone for tourism and mixed uses (Commercial and Business);

3) The Natural Park Zone (Environmental and Nature Conservation Park);

4) North Urban Zone (Largely new residential area); and

5) South-Urban Zone (Existing new residential with commercial and mixed uses as well as light industry.

In addition, the updated land use master plan will provide a total built-up area of about 10,380 hectares and will accommodate a residential population of about 3.4 Million persons and non-residential population, such as tourists, hotels, commercial, offices, medical (hospitals, clinics and maternity homes) and industrial, of about 1.9 Million persons [16]; and see Figures 1(a) and (b).

The relief is plain land of not up to $50 \mathrm{~m}$ above sea level anywhere. It is poorly drained. There is water on $32 \%$ of the land surface for more than 75 percent of the days of the year. Its sandy beaches, including Elegushi, Lekki/Eleko Beach and Oso Lekki Backwaters, and relics of Brazilian/Portuguese and other imposing architectures make Lekki a tourism goldmine. Industrial establishments are not common, but there are small scale enterprises. Most unique is the Headquarters of Chevron Nigerian Limited (one of the multinational oil companies in 


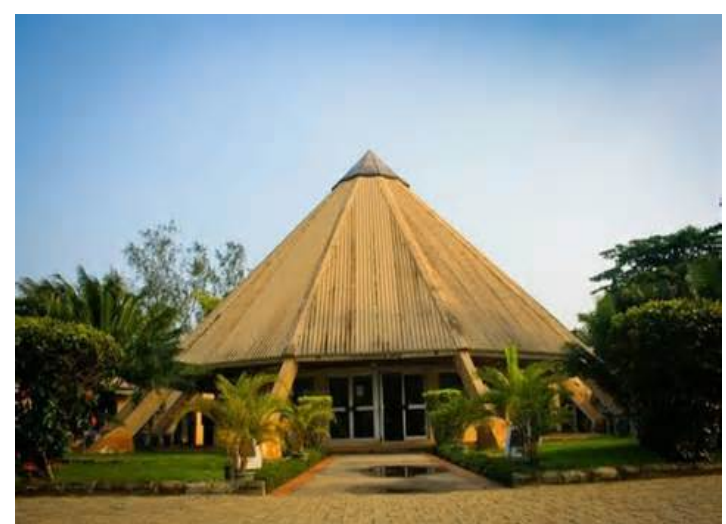

(a)

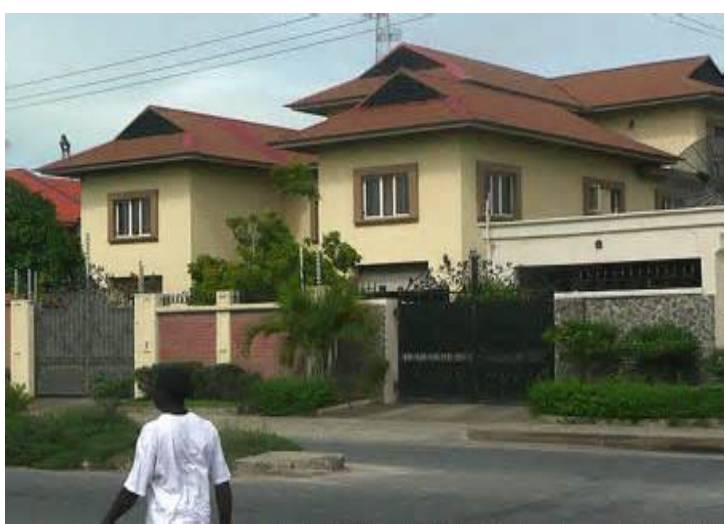

(b)

Figure 1. (a) One of the private recreation centers in Lekki; and (b) Blocks of flats in an estate at Lekki.

Nigeria). There are many shopping complexes, housing estates, hotels and brothels and mammy Markets. Housing in Lekki is usually in blocks of adjoining flats. See Figures 1(a) and (b). Over 95\% of homes are furnished with running water from boreholes and electricity. Standard three-bedroom flat rent goes for between N2.5 and N3.0 million per annum. The area is poorly served by buses and taxis as most residents have their own cars. The popular Ilasan market, otherwise known as Lekki Market by expatriates, sells fruits, vegetables, art and artifacts from Nigeria and other parts of West Africa. However, prices are higher than in other parts of Lagos Metropolis.

There are a number of hotels, brothels and restaurants notably, Radisson Hotel, Piccadilly Hotel, Peninsula Hotel, Noah's Ark Hotel and Suites, Peninsula Resort, La Champagne Tropicana, The Stone House Boutique Hotel, Citi Lodge Hotel, Cristobel Palace and Apartments. Available rooms of different status range between 24 and 75. The rates range between N25,000:00 and N85,000:00 per night. Lunch is not less than N3500:00 in any; and it is as much as N8500:00 in others. The Anap Ranch at kilometer 42 on Epe Expressway sells imported Dutch stock meat (a brand of imported beef), ground beef (bush meat), bone/rib steaks and rump roast. Lekki also has seaside pleasure garden and water sports that attract tourists from far and near particularly at festive periods.

The Lekki Corridor is seen as one of the most dynamic growth areas in Lagos State where it provides an enormous opportunity to satisfy the increasing demands of Lagos, Lagosians and foreigners alike [17]. The Peninsula is a developing suburb considered a prime real estate location; and a growth pole; there is a Free Trade Zone Port coming up. See Figure 2; a 5000 capacity Stadium; and an Eighteen Holes Golf Course were just completed. Apart from service roads, there is a six lane expressway that runs almost parallel to the sea and serves the peninsula throughout its length.
Also, apart from Jakande Market, the Spar Super Market and Ajah Market, commercial activities are springing up along major streets and roads. Industrialization activities are at very low web; and over 80 per cent of the residents commute to work on Victoria Island south westward and beyond. This probably explains why traffic is always heavy towards Victoria Island from Lekki in the morning between the hours of 06:00 and 10: $00 \mathrm{am}$; and out of Victoria Island to Lekki between the hours of 16:30 and 10:00 pm, that is, for resumption of work and closing from work respectively. There is massive movement of people and businesses to the peninsula on daily basis.

\section{Methods}

Observations were made on households, commercial centers, hotels, brothels and recreation centers for one year (2012) to find out the sources of water used. Samples of water were taken from 25 borehole sources. 55\% were from residential boreholes, $25 \%$ were institutional, $10 \%$ were commercial and the others were $15 \%$. The sampled boreholes were not less than $100 \mathrm{~m}$ apart. The depth and general water tables were determined. The samples were taken three times from each of the sampled sources within the period of study: March, July and November. Each time, they were well preserved according to the World Health Organization [18] specification, and analyzed within two days of collection of each using the WHO acceptable standards for comparison. Over $85 \%$ of the samples were tasted. In-Depth-Interviews were conducted with residents, community leaders, business men and women on the snags of water, potentials of Lekki peninsulas and others. Director, Physical Planning of the Lagos State Ministry of Environment and the State Water Corporation were similarly interviewed and relevant data and information were collected from these sources. Tables and maps were used for presentation of the data and information collected. The researcher listened to 


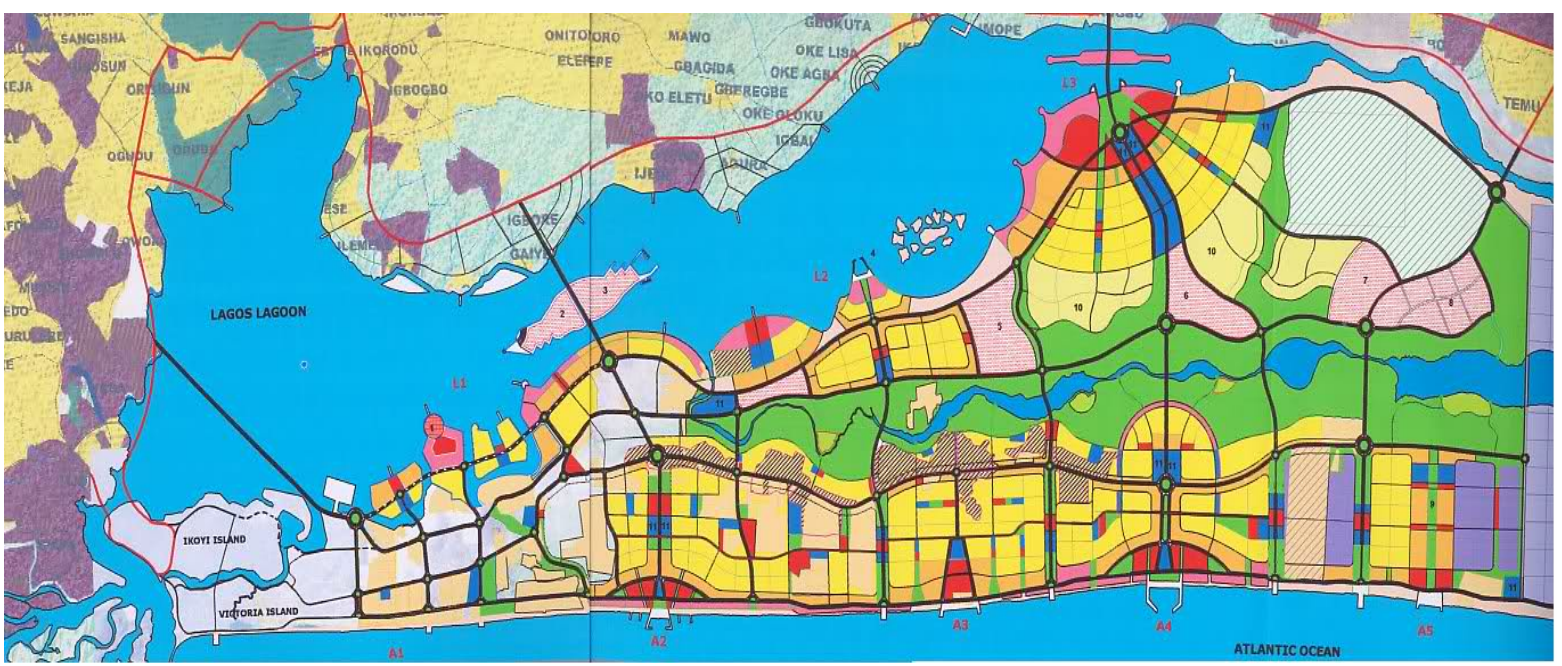

Figure 2. Lekki mega city plan.

radio and television documentaries; and newspapers were read.

\section{Findings}

There are 12 sources of water the residents use: Ocean, seas, swamps, rain and dews, mairuwa, sachet, bottled, boreholes, ponds and lakes, rivers and streams, and others. No pipe borne water anywhere at Lekki. $1.50 \%$ each depends on ocean, seas and other sources. $1.00 \%$ uses rivers and streams; and 4.50\% uses swaps. See Table 1. Over 90\% (91.00\%) depend on bottled water; and every household, business, office, restaurant and bar, hotel, brothel, schools and colleges, recreation and tourist center and others (100:00\%), use bore holes drawn into plastic tanks from where it is distributed to point of use.

MaiRuwa, water tanker drivers, rain and dews are also sources of water that as much as $2.50 \%, 12.50 \%$ and $5.50 \%$ respectively depend; see Table 1 . Apart from surface water from streams, ocean bodies and seas, the water table is low, less than 8 meters. Suffice it to say that there is water on over $65 \%$ of the land surface for over $75 \%$ of the days of the year. In other words, the peninsula is sandy swamp.

But, Table 2 shows average chemical composition of the bottled water commonly circulated. Average $\mathrm{pH}$ is 7.1, conductivity is 91, Calcium is 15 and Magnesium is 1. Other readings; Chloride (10) and Sulphate (5) compared with the WHO [12] standards. See Table 2. They go by the names: Gossey, Nestle water, Miles Table Water, eva, cascade and others. The bottles are usually of between 50 and $150 \mathrm{cl}$ capacities.

Each company advertises its own as potable water that meets WHO standard for consumption. One of them has this to say on the label found on the bottle:

...don't wait to be thirsty; regular drinking prevents dehydration. delivered water so pure, we promise there
Table 1. Sources of water at Lekki.

\begin{tabular}{cc}
\hline Sources of Water & Proportion of Dependence (\%) \\
\hline Ocean & 1.50 \\
Seas & 1.50 \\
Pipe Borne Water & 0.00 \\
Sachet Water & 58.00 \\
Bottled Water & 91.00 \\
Boreholes & 100.00 \\
Ponds \& Lakes & 4.00 \\
Rivers \& Streams & 1.00 \\
Swamps & 4.50 \\
Mai Ruwa & 2.50 \\
Water Tanker Drivers & 12.50 \\
Rain \& Dew & 5.50 \\
Others & 1.50 \\
\hline
\end{tabular}

Table 2. Chemical analysis of bottled water at Lekki.

\begin{tabular}{ccc}
\hline Parameters & Mean Results (mg/l) & WHO Standards (mg/l) \\
\hline pH & 7.1 & $6.5-8.5$ \\
Conductivity & 91 & 1000 \\
Calcium & 15 & 95.00 \\
Magnesium & 1 & 2 \\
Sodium & 9 & \\
Potassium & 2 & \\
Chloride & 10 & 0.1 \\
Nitrate & 0 & 100 \\
Sulphate & 5 & \\
Bi-carbonate & 52 & 150 \\
Phosphate & 0 & Varied with Regions \\
Total Mineral & 124 &
\end{tabular}


is nothing but crisp, clean refreshment in every bottle. So go ahead and enjoy a great tasting...

But this source is beyond the reach of over $80 \%$ of the residents. Those that can afford it spend over $15 \%$ of their income to have enough.

The boreholes are not more than $30 \mathrm{~m}$ and not less than $30 \mathrm{~m}$ anywhere. Samples from this source were also further examined. Table 3 shows the average Physical/ Organoleptic Analysis of water sampled from 25 boreholes. 10 parameters were examined (visual appearance, temperature, colour, odour, taste, filling volume, turbidity, conductivity, salinity and total dissolved solid materials). See Table 3. Visual appearance is brownish as against "clear". Temperature is slightly higher by about $2^{\circ} \mathrm{C}$, and it has slight taste as against odourless and tasteless respectively recommended by World Health Organization (WHO) [12]. Turbidity (16.5) and conductivity (325) are intolerantly high and low respectively. The standard for salinity is not available but a taste of the samples indicates some salinity; and the dissolved solid materials are relatively low, 238; see Table 3 .

The chemical analysis compared with the WHO standards is also shown in Table 4. 20 parameters were tested: There were no results for copper, arsenic and cadmium elements; and standards for total acidity and organic matters (as hmno 4) were not available for comparison. But, the $\mathrm{pH}(6.1)$ is averagely about 0.4 lower than the lower limit of the standard. See Table 3.

Residual Chlorine (mg/l), iron (mg/l), Nitrate (mg/l), Nitrite (mg/l), Zink (mg/l) and magnesium $(\mathrm{mg} / \mathrm{l})$ are absolutely absent, zero values. Total alkalinity ((mg/l), total hardness (mg/l), Calcium hardness (mg/l), Magnesium hardness (mg/l), Chloride (mg/l) Sulphate (mg/l), and free Carbon Dioxide are considerably too low (7.0, 48, 20, 28, 55.8 and 6.16 respectively); see Table 4.

Average results of Microbiological Analysis of the samples are shown in Table 5. 9 microbial groups were

Table 3. Physical/organoleptic analysis of borehole water at Lekki.

\begin{tabular}{ccc}
\hline Parameter & Mean Result & $\begin{array}{c}\text { WHO } \\
\text { STANDARDS }\end{array}$ \\
\hline Visual Appearance & Brownish & Clear \\
Temperature of Water & $25 / 28$ & $27 / 28$ \\
Colour & 200 & Colourless \\
Odour & Smells & Odourless \\
Taste & Slight Taste & Tasteless \\
Filling Volume, cl & $0.57 \mathrm{cl}$ & \\
Turbidity, NTU & 16.5 & 5 \\
Conductivity, us/cm & 325 & 1000 \\
Salinity, $\mathrm{Mg} / \mathrm{I}$ & 176 & \\
Total Dissolved Solid, $\mathrm{Mg} / \mathrm{I}$ & 238 & 500 \\
\hline
\end{tabular}

Table 4. Chemical analysis of borehole water at Lekki.

\begin{tabular}{|c|c|c|}
\hline Parameters & Mean Results & WHO Standards \\
\hline $\mathrm{pH}$ & 6.1 & $6.5-8.5$ \\
\hline Residual Chlorine. Mg/I & 0.0 & $0.2-0.5$ \\
\hline Total Alkalinity, Mg/I & 7.0 & 100 \\
\hline Total Acidity, Mg/I & 4.0 & - \\
\hline Total Hardness, Mg/I & 48 & 400 \\
\hline Calcium Hardness, Mg/I & 20 & 200 \\
\hline Magnesium Hardness, Mg/I & 28 & 50 \\
\hline Iron $\mathrm{Mg} / \mathrm{I}$ & 0.0 & 0.3 \\
\hline Chloride Mg/I & 55.8 & 250 \\
\hline Nitrate, $\mathrm{Mg} / \mathrm{I}$ & 0.0 & 50 \\
\hline Nitrite, Mg/I & 0.0 & 0.1 \\
\hline Sulphate $\mathrm{Mg} / \mathrm{I}$ & 12 & 100 \\
\hline Copper, Mg/I & - & 1.0 \\
\hline Arsenic, Mg/I & - & 0.1 \\
\hline Cadmium, Mg/I & - & 0.003 \\
\hline Zinc, Mg/I & 0.0 & 50 \\
\hline Lead, Mg/I & 0.0 & 0.005 \\
\hline Magnesium, Mg/I & 0.0 & 2.0 \\
\hline Free Carbon Dioxide & 6.16 & 50 \\
\hline Organic Matter as $\mathrm{KMnO}_{4}$ & 0.13 & \\
\hline
\end{tabular}

Table 5. Microbiological analysis of borehole water at Lekki.

\begin{tabular}{ccc}
\hline Microbial Group & Average Reading & Limit (Cfu/ml) \\
\hline Aerobic Mesophilic & $55+$ & $10^{2}$ \\
Coliforms, MPN & 15 & 0 \\
Salmonella & - & 0 \\
Shigella & - & 0 \\
Staphyaureus & - & 0 \\
Streptococcus faecal & - & 0 \\
Bacillus Sp & - & 0 \\
Listeria & - & 0 \\
Vibrio & - & 0 \\
\hline
\end{tabular}

used. The readings for salmonella, Shigella, Staphyaureus, Bacillus Sp., Listeria and Vibrio groups were negative (zero values). Conversely, Aerobic Mesophilic (55+) is within the limit of 102; but Coliforms (MPN) is terribly high, 15 as against nil recommended limits. See Table 5 .

Towards meeting potability, averagely, whooping 15\% of individual incomes are expended; and slightly above 
this proportion is spent by corporate organizations. Detail discussions of these are beyond the scope of this work, but suffice it to say that the economic cost is high. Whereas, the target of the Millennium Development Goal (MDG) is to reduce, by half, the proportion of people without access to basic sanitation by the year 2015 .

\section{Towards Sustainable Potable Water}

There could be many means of achieving portable water $[7,12,19-21]$ but this work is suggesting a Water Treatment Device that is simple, sustainable and cost effective [22]. There are four Chambers; see Figure 3.

Chamber I-Contains raw water from the borehole. From the foregoing, the raw water is brownish in colour, smells, contains organic and inorganic particles, impurities like unwanted mineral salts, bacteria, dissolved air, organic remains; and unfit for use.

Chamber II-Is another plastic tank that will contain alum. The alum will make the particles to settle substantially.

Chamber III-This contains activated carbon (absorbent material) that absorbs finer particles, tastes, odour and part of the colour. It gets rid of those organic materials and dust particles that might have escaped from the second Chamber.

Chamber IV-Is a single filter device. It filters the finest particles that might have passed through the second and third Chambers, if any. What passed out of the fourth Chamber is therefore potable water that meets WHO permissible standard.

The raw water is from the bore hole (but it could be from any source-river, pond, lake, swamp and others). The Chambers are made of galvanized aluminum metals coated with zinc, that is, to prevent rusting. But, the fist and the last Chambers may be GEEP plastic tanks. See Figures 3(a) and (c). Addition of alum (hydrated potassium/aluminum sulfate) is to make the organic impurities like dust particles and other suspensions increase in density and settle as sediments. Chlorine may be added in the third Chamber but it reacts with organic materials to form some harmful compounds; and it may result in brownish colour again [22-24]. The chemical may be added to the Chamber or in separate device, see Figure 3(d) - a filter and Chlorine compartment. Also to increase the purity of the water and make it $100 \%$ suitable for drinking, additional device may be added, see Figures 3(e) and (f)-advanced forms of filters. On the whole, there will be about 13 valves depend on the positioning of the Chambers: Apart from the valve that releases water to the point of use, there will be a valve each between the four chambers; between the bore hole and the first Chamber, and one each between each Chamber

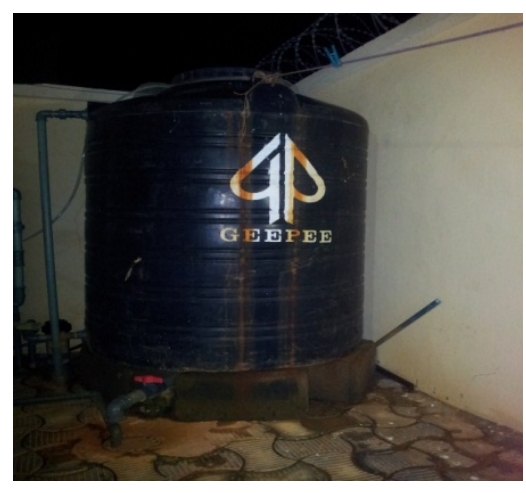

(a)

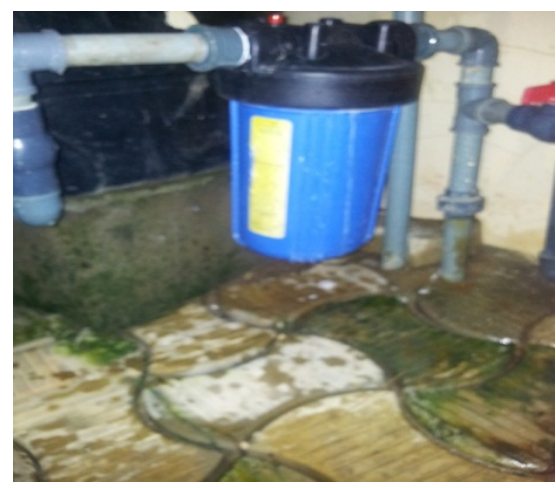

(d)

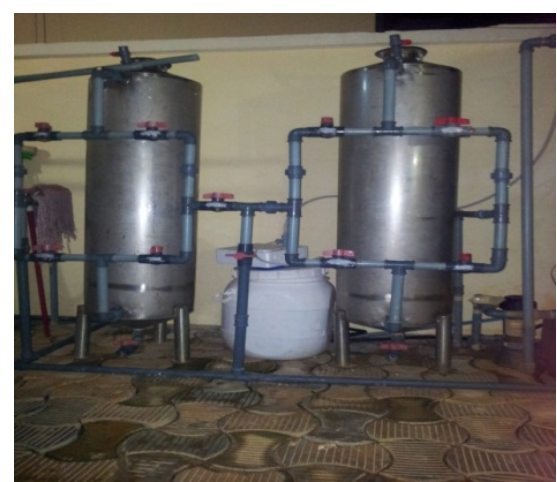

(b)

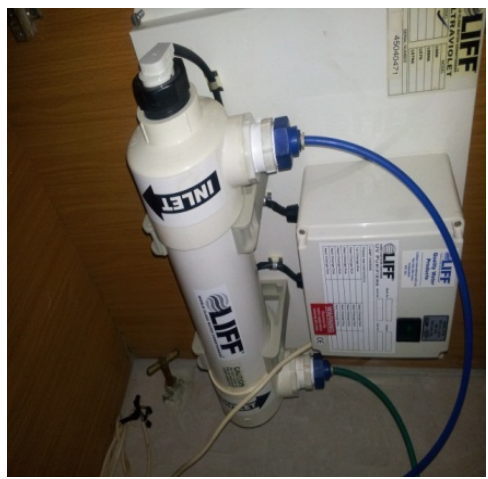

(e)

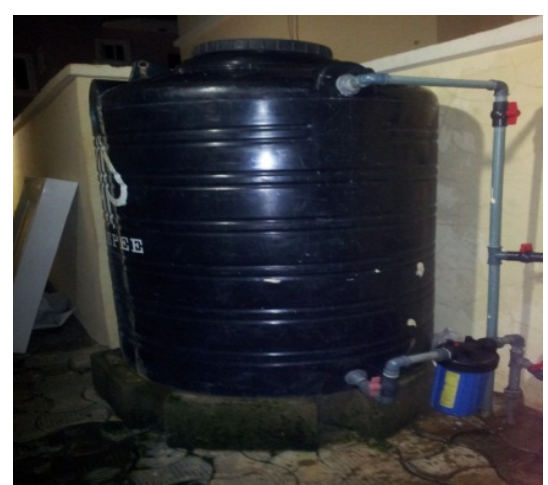

(c)

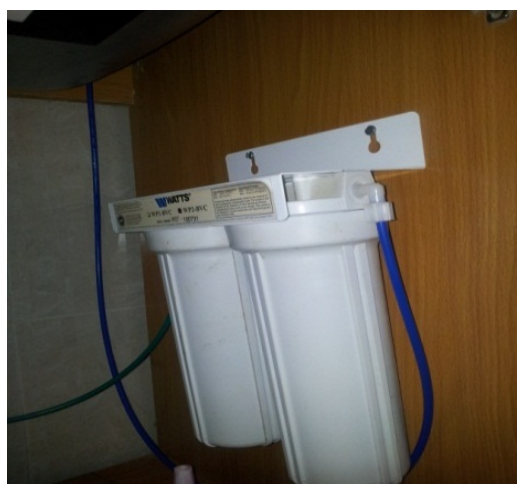

(f)

Figure 3. Major components of a water purifying device. 
and the waste pipes for backwashing. Backwashing is the means of cleaning the entire system of dirt. Backwashing is best at a rate of once in a week (depends on usage, it may be more frequent if the volume of passage is frequent and high). Suffice it to say that the entire system is powered by electricity. There will be three (3) pumping machines - one submersible and two, surface. The submersible machine takes water from the source (raw water) to the storage chamber (Chamber I). It is the first surface machine that pumps from the raw water tank to the treated water tank (Chamber II). The third pump, (surface pump) takes the water up to the last tank from where it is distributed to the points of use.

\section{Discussion and Conclusions}

Quality of drinking-water is a powerful environmental determinant of health. Assurance of safety of drinking-water is a foundation for the prevention and control of waterborne diseases. This work has established that there is plenty of surface and underground water in Lekki Peninsula but cannot support sustainable development in this new lay-out of Lagos Metropolis that is fast growing. Major sources are sachet and bottled water; and self-dug and maintained bore holes. This work cannot confirm the chemical composition and quality of the sachet waters but it is the commonest sophisticated followed by bottled waters in various sizes of plastic bottles. Over 98\% of them compared favourably with the WHO acceptable standards, (pH, conductivity, Nitrate, Sodium, Magnesium, Chloride, bicarbonate, Phosphate, Potassium and others). But this source is expensive and out of reach of many; and to those that can afford it, it takes substantial amount of their monthly income. Other source used by all is the borehole dug by individual households, businesses and organisations. But it is associated with poor quality attributes: Often, the results of physical/organoleptic analysis (visual appearances, colour, odour, tastes, turbidity, conductivity, salinity and total dissolved solid matters) were at variance with the WHO standards. Also, the chemical analysis (residual Chloride; total alkalinity, acidity; hardness of Calcium, and Magnesium; iron, chloride, Nitrate, Nitrite, Sulphate, Copper, Arsenic, Cadmium, Zinc, Lead, Manganese (in $\mathrm{mg} / \mathrm{l}$ ); free Carbon Dioxide and organic matters (as $\left.\mathrm{KMnO}_{4}\right)$ are high and at variance with the WHO acceptable standards of potable water.

The microbiological analysis shows it is only Coliform that is higher than the acceptable standard. Others are within limits. But the high content of Coliforms and other chemical and physical/organoleptic variance make this source unsustainable. In order to meet the target of Millennium Development Goals and the WHO specifications, sustainable sources must be sourced; and at reasonable cost too. The current spates of spending; and dependent on unsustainable sources have to be ameliorated; and or others sourced. These therefore call for the Simple Water

\section{Treatment Device.}

This has several advantages, namely:

1) It will control water borne diseases such as typhoid, schistotomiasis, diarrhea and dysentery, hepatitis, cholera and others;

2) Potable water will be readily available for domestic, recreational and industrial uses;

3) Potable water will be available for use in the Free Trade Zone and at the forth coming airport;

4) The Eighteen Hole Golf Course will not have challenge of potable water either; and

5) Military formations within and around the peninsula can rely on the source for domestic and small scale enterprises.

It is estimated that a system that will provide average of 100,000 liters a day will cost 720,000:00, that is, outside the cost of electricity to power the system. Estates, Community Development Associations (CDAs) and Local Governments can venture into the provision of potable water through this device.

\section{REFERENCES}

[1] T. Odumosu and K. Aderogba, "Infrastructures for Development in Nigeria: Electricity and Water," Journal of Social and Policy Issues, Vol. 3, No. 2, 2008, pp. 56-62.

[2] K. A. Aderogba, "Contemporary Water Supply Situations and Alternatives in Nigeria Schools and Colleges: Implications for Public Policy,” Perspective on Globalization, Development and Public Policy, Afro-Euro Centre for Development Studies, 2008, pp. 395-407.

[3] K. A. Aderogba, "Environmental Consequences of Sachet and Bottled Water Usage in the Cities and Towns West of Niger River, Nigeria,” International Journal of Literacy Education, Department of Adult Education, University of Ibadan, Ibadan, Vol. 6, No. 1, 2009, pp. 153-170.

[4] K. Aderogba, M. Oredipe and B. Komolafe, "Power Supply and Challenges of Sustainable Development in Nigeria,” In: A. Ogidiolu, S. D. Musa and Ifatimelin, Eds., Contemporary Issues in Infrastructural Development and Management in Nigeria, Association of Nigerian Geographers, 2010, pp. 371-382.

[5] U. Mutallab, "The Business Support Group of Nigeria Vision 20:2020,” The Presidency and Nigeria Vision 2020, Abuja, 2011.

[6] A. L. Mabogunje, "Nigerian Environment in the New Millennium,” Federal Environmental Protection Agency, Abuja, 1999.

[7] World Health Organization, "Global Costs and Benefits of Drinking-Water Supply and Sanitation Interventions to Reach the MDG Target and Universal Coverage,” World Health Organization, Geneva, 2012.

[8] World Bank, "Progress with Millennium Development Goal (A Progress Report),” World Bank, Washington DC, 2008. 
[9] Energy Information Administration, "Country Analysis Brief-Nigeria. Energy Information Administration,” EIA. Department of Energy, US Government, Washington DC, 2007.

[10] A. Y. Hoekstra and A. K. Chapagain, "The Water Footprints of Nations: Water Use by People as a Function of Their Consumption Pattern," Water Resource Management, Vol. 21, No. 1, 2007, pp. 35-48. http://dx.doi.org/10.1007/s11269-006-9039-x

[11] J. D. Marshall and M. W. Toffel, "Framing the Elusive Concept of Sustainability: A Sustainability Hierarchy," Environmental \& Scientific Technology, Vol. 39, No. 3, 2005, pp. 673-682. http://dx.doi.org/10.1021/es040394k

[12] World Health Organization/UNICEF, "Progress on Drinking Water and Sanitation: 2012 Update,” United Nations' Children's Fund and World Health Organization, New York, 2012.

[13] American Heritage Dictionary, "World Histories and Mysteries: From Abracadabra to Zeus,” Houghton Mifflin Harcourt, 2004, p. 216.

[14] R. Clarke and J. King, “The Atlas of Water,” Earthscan, London, 2006.

[15] Lagos State Government, "Environmental Sanitation Edict No. 12 Supplement to Lagos State of Nigeria Official Gazette Extraordinary,” Vol. 35, No. 18, 1985.

[16] Lagos State Government, "Lagos State and the New Layouts,” Ministry of Environment and Physical Planning, Lagos, 2012.

[17] O. A. Ibidun, "Vulnerability of Poor Urban Coastal Communities to Climate Change in Lagos, Nigeria,” Fifth Urban Research Symposium, 2009.
[18] World Health Organization, "Guideline for the Safe Use of Wastewater, Excreta and Greywater, Volume 2: Wastewater Use in Agriculture," World Health Organization, Geneva, 2006.

[19] W. C. Clarke, “The Structure of Permanence: The Relevance of Self-Subsistence Communities for World Ecosystem Management,” In: T. Bayliss-Smith and R. Feachem., Eds., Subsistence and Survival: Rural Ecology in the Pacific, Academic Press, London, 1977, pp. 363-384. http://dx.doi.org/10.1016/B978-0-12-083250-7.50017-0

[20] M. Redcliff, “The Meaning of Sustainable Development,” Geoforum, Vol. 23, No. 3, 1992, pp. 385-404. http://dx.doi.org/10.1016/0016-7185(92)90050-E

[21] World Health Organization/UNICEF, "International Network on Household Water Treatment and Safe Storage: Revised Strategy and Funding Proposal,” World Health Organization, United Nations Children’s Fund, Geneva, 2013.

[22] E. Orakpo, "Water Treatment Device: A Weapon to Control Water-Borne Diseases,” Vanguard Learning. Vanguard: Towards a Better Life for the People, Vanguard Media Limited, Lagos, Vol. 25, No. 61881, 2013, p. 32.

[23] H. Shuval, "Estimating the Global Burden of Thalassogenic Diseases: Human Infectious Diseases Caused by Wastewater Pollution of the Marine Environment," Journal of Water and Health, Vol. 1, No. 2, 2003, pp. 53-64.

[24] S. V. Flanagan, R. B. Johnston and Y. Zheng, "Arsenic in Tube Well Water in Bangladesh: Health and Economic Impacts and Implications for Arsenic Mitigation,” Bulletin of the World Health Organization, No. 90, 2012, pp. 839-846. http://dx.doi.org/10.2471/BLT.11.101253 